\title{
Sarah Bellamy, the women transported to Botany Bay, biographical genres and the Australian Dictionary of Biography ${ }^{1}$
}

\author{
MELANIE NOLAN, CHRISTINE FERNON AND REBECCA KIPPEN
}

Surely using different kinds of sources results in different kinds of writing? Of course it is a matter of degree with both imagination and empirical research informing novels and biography on a continuum: sometimes novelists research and historians sometimes imagine. Charlotte Brontë's novel Shirley (1849) was based on her research of the Leeds Mercury newspaper of 1814 to $1816 .^{2}$ Some historians, while wary of crossing genres and writing fiction, have no problem using contemporary historical literature. Thomas Carlyle wrote a novel in 1836 before writing biographies of great male leaders and lesser ones on his friends and relatives. ${ }^{3}$ Certainly, different kinds of biography tend to rest more heavily on different kinds of sources. Hamish Maxwell-Stewart and Lucy Frost observed that convict biography based on fragmentary and biased sources involves epistemological concerns:

The intellectual challenge faced by anyone who was to narrate convict lives is epistemological; what meanings can we legitimately attach to documents (textual or material) which are the source for knowing the past? How can we narrate the lives of people long dead? [... as] a conceptual problem, the issue is highly complex and theoretical. ${ }^{4}$

This has not dissuaded the writing of convict biography. Prosaically, historians tend to use mixed methods considering multiple viewpoints, perspectives, positions and standpoints, and both qualitative and quantitative sources. ${ }^{5}$ They tend

\footnotetext{
1 We thank Matt Cunneen and Nichola Garvey and the anonymous referees for their comments on an earlier draft; and Jenni Bird for her advice.

2 Melanie Nolan, 'Industrialisation', in A Companion to Women's Historical Writing, ed. Mary Spongberg, Barbara Caine and Ann Curthoys (Basingstoke: Palgrave Macmillan, 2005), 256. See also Elizabeth Gaskell, The Life of Charlotte Brontë (1966, f.p. 1857), 378.

3 Thomas Carlyle, Sartor Resartus (1836); the novel was first published as a serial in Fraser's Magazine in November 1833 to August 1834.

4 Lucy Frost and Hamish Maxwell-Stewart, 'Introduction', in Chain Letters: Narrating Convict Lives, ed. Lucy Frost and Hamish Maxwell-Stewart (Carlton South, Vic.: Melbourne University Press, 2001), 4, cited by Jenni Bird, 'Reconstructing a Convict Life: Archives, Fragmentary Evidence and Convict History', unpublished PhD thesis draft, ch. 1, n.p.

5 Johnson R. Burke, Anthony J. Onwuegbuzie and Lisa A. Turner, 'Towards a Definition of Mixed Methods Research', Journal of Mixed Methods Research 1, no. 2 (2007): 113.
} 
'to triangulate' or use multiple methods and data sources in their research to develop a comprehensive understanding of phenomena. ${ }^{6}$ The biography of the 'First Fleeter' Sarah Bellamy and how the Australian Dictionary of Biography $(A D B)$ deals with biographical genres more generally are cases in point.

Bellamy was born about 1770 and died in 1843 . Her entry in Wikipedia notes that she was 'one of the longest-living first fleeters' of those who left England in 1787 and arrived in Botany Bay in 1788..$^{7}$ However, as we shall see, being among the long-lived first fleeters is only one of her claims to fame and, even then, a number of former convicts lived longer in the colony than her. ${ }^{8}$ In the past she fell between categories of the $A D B$ in terms of her significance or representativeness. She was not included in the 2 colonial volumes published in 1966 and 1967. ${ }^{9}$ More surprising, perhaps, given reference to her life in subsequent historiography, as is described below, she was not included in the $A D B$ 's 'missing persons' volume, published in 2005. ${ }^{10}$ So, currently, Bellamy's common-law husband James Bloodworth has an $A D B$ entry. ${ }^{11}$ Arthur Bowes-Smyth, the surgeon on the First Fleet transport on which she travelled, has an entry in the $A D B \cdot{ }^{12}$ Bellamy soon will have one. She is at the centre of a number of $A D B$ revision and research projects, as well as the dictionary's emerging interest in prosopography. ${ }^{13} \mathrm{Her}$ story provides an opportunity to discuss both biographical genres as well as how

6 Anna Green and Kathleen Troup, eds, The Houses of History: A Critical Reader in Twentieth-Century History and Theory (Manchester: Manchester Unity Press, 1999), 236.

7 'Sarah Bellamy', Wikipedia, accessed 1 September 2020, en.wikipedia.org/wiki/Sarah_Bellamy.

8 John Cobley, The Crimes of the First Fleet Convicts (Sydney: Angus and Robertson 1982), 22, noted that in 1828 Sarah was one of at least 19 women of the First Fleet who were still alive.

9 Australian Dictionary of Biography, vol. 1, A-H (Melbourne: Melbourne University Press, 1966) and Australian Dictionary of Biography, vol. 2, I-Z (Melbourne: Melbourne University Press, 1967).

10 Christopher Cunneen with Jill Roe, Beverley Kingston and Stephen Garton, eds, Australian Dictionary of Biography, Supplement 1580-1980 (Carlton, Vic.: Melbourne University Press, 2005).

11 Morton Herman, 'Bloodsworth, James ([c.1759]-1804)', Australian Dictionary of Biography online, National Centre of Biography, The Australian National University (hereafter $A D B$ online), www.adb.online.anu.edu.au/biogs/ A010112b.htm, published first in hardcopy 1966. The surname was spelt variously as Bloodsworth and Bloodworth contemporarily, but descendants are all Bloodworth. We have decided to refer to him as Bloodworth in this article.

12 'Smyth, Arthur Bowes (1750-1790)', $A D B$ online, adb.anu.edu.au/biography/smyth-arthur-bowes-2674, published first in hardcopy 1967.

13 For a discussion of the wider revision project of the $A D B$, see Melanie Nolan, 'Who Deserves to be in the Australian Dictionary of Biography?', The Conversation, 7 April 2011, theconversation.edu.au/profiles/melanienolan-183; Melanie Nolan, 'Missing in Action', Inside Story, 16 March 2017, insidestory.org.au/missing-in-action; and Melanie Nolan, 'Time to Revise Entries', ANU Reporter 49, no. 3 (Spring 2018): 60, reporter.anu.edu.au/ time-revise-entries; Paul Daley, 'Decolonising the Dictionary: Reclaiming Australian History for the Forgotten', Guardian, 17 February 2019, theguardian.com/books/2019/feb/17/decolonising-the-dictionary-reclaiming-historyfor-the-forgotten; Frank Bongiorno, 'Reframing Australian Portraits', Meanjin, Winter 2019, meanjin.com.au/ essays/reframing-australian-portraits/; Shino Konishi, 'Redressing the Imbalance of Representation in the Australian Dictionary of Biography', University of Western Australia, www.uwa.edu.au/projects/indigenous-biography-project; Shino Konishi, 'An Indigenous Australian Dictionary of Biography', in "True Biographies of Nations?" The Cultural Journey of Dictionaries of National Biography, ed. Karen Fox (Canberra: ANU Press, 2019), 139-58, doi.org/10.22459/ TBN.2019; Georgina Arnott, 'Links in the Chain: Legacies of British Slavery in Australia', Australian Book Review, no. 423 (August 2020), www.australianbookreview.com.au/abr-online/current-issue/author/15126-georginaarnott. All websites accessed 24 August 2020. 
the $A D B$-an eminent work in itself-is changing. The $A D B$ is often described as a monumental piece of scholarship: the largest and most successful cooperative research enterprise in the humanities and social sciences in Australia. More than 13,000 concise biographies of significant and representative Australians, who died prior to 1996 , have been written by historians and other scholars, and published by the $A D B$ over the last 60 years. The $A D B$ went online in July 2006. It is now more than the book online, and is contributing to new approaches to biography, including prosopographical projects and group biographies as well as concise biographical essays on subjects previously overlooked. Indeed, the $A D B$ is in the process of being revised to reflect more contemporary and nuanced understandings of the past in regard to Indigenous, women and working-class biography. ${ }^{14}$ One of our major projects, the 'First Three Fleets and Their Families' project focus is the 4,500 or so people who set off in the first 3 fleets to New South Wales between 1787 and 1791. It examines how those who survived the journey 'remade' their lives in the infant colony. The project is also investigating how their children and grandchildren fared. Records for all the fleeters and their families are being added to the National Centre of Biography's (NCB) People Australia website. ${ }^{15}$ The NCB has also initiated a Colonial Women revision project to increase the number of women in the $A D B$ who 'flourished' in the colonies before 1901 . Bellamy has found a place in both projects. A consideration of the issues of genres and the sources and ways of writing a life such as Sarah Bellamy's is proxy for all the women convicts transported to Botany Bay on the First Fleet.

\section{Unthinkable history? Only fictional accounts?}

Few women convicts were included in the first 2 volumes of the $A D B$ that covered the period 1788 to 1850 . Owing to the contemporary dearth of records, Bellamy and the lives of other women transported from England to arrive in Botany Bay in January 1788 have been described as 'unthinkable history'. ${ }^{16}$ These women were regarded as voiceless: without diaries, letters or even records of their statements at court. For instance, one of the students that Nolan and Kippen are supervising has estimated, from the trial records of Old Bailey, London, that a group of convict women on the Second Fleet ship Neptune only spoke on average 46 words, or 2 or 3 sentences, in their own defence. They ranged from only 5 words to 130 at most. ${ }^{17}$

\footnotetext{
14 David Andrew Roberts, “"The 'Knotted Hands That Set Us High”: Labour History and the Study of Convict Australia', Labour History, no. 100 (May 2011): 33-50, discusses 'disciplinary silos' in regard to convict history.

15 People Australia, at: peopleaustralia.anu.edu.au/.

16 Joan Contessa Phillip, 'Sarah Bellamy of Belbroughton Parish: A Poor Prisoner Speaks With Her Own Breath', ch. 14 in 'The Dream-Or, An Unthinkable History Written in Memory of Women Transported to Botany Bay 1787-1788' (PhD thesis, University of New South Wales, 2008), 328-58.

17 For instance, Old Bailey Records, 9 September 1789, The Proceedings of the Old Bailey, 1674-1913, www.old baileyonline.org/, cited by Nichola Garvey, 'Second Fleet Women, First-Rate Survivors', unpublished PhD draft.
} 
Of course men had only a few more words recorded in court proceedings than women and were thus similarly without voice. Of the First Fleet women, 53.7 per cent were sentenced at the Old Bailey, London. ${ }^{18}$ In Bellamy's case there are not even verbatim records of the Assizes session at which she was sentenced. She left no writing and we have no image of her except the report of her long red hair. The extent of description possible for convict women was considered too thin in the 1960s when the $A D B$ entries on the period of transportation were written. Surely there is only so much we can say about some people?

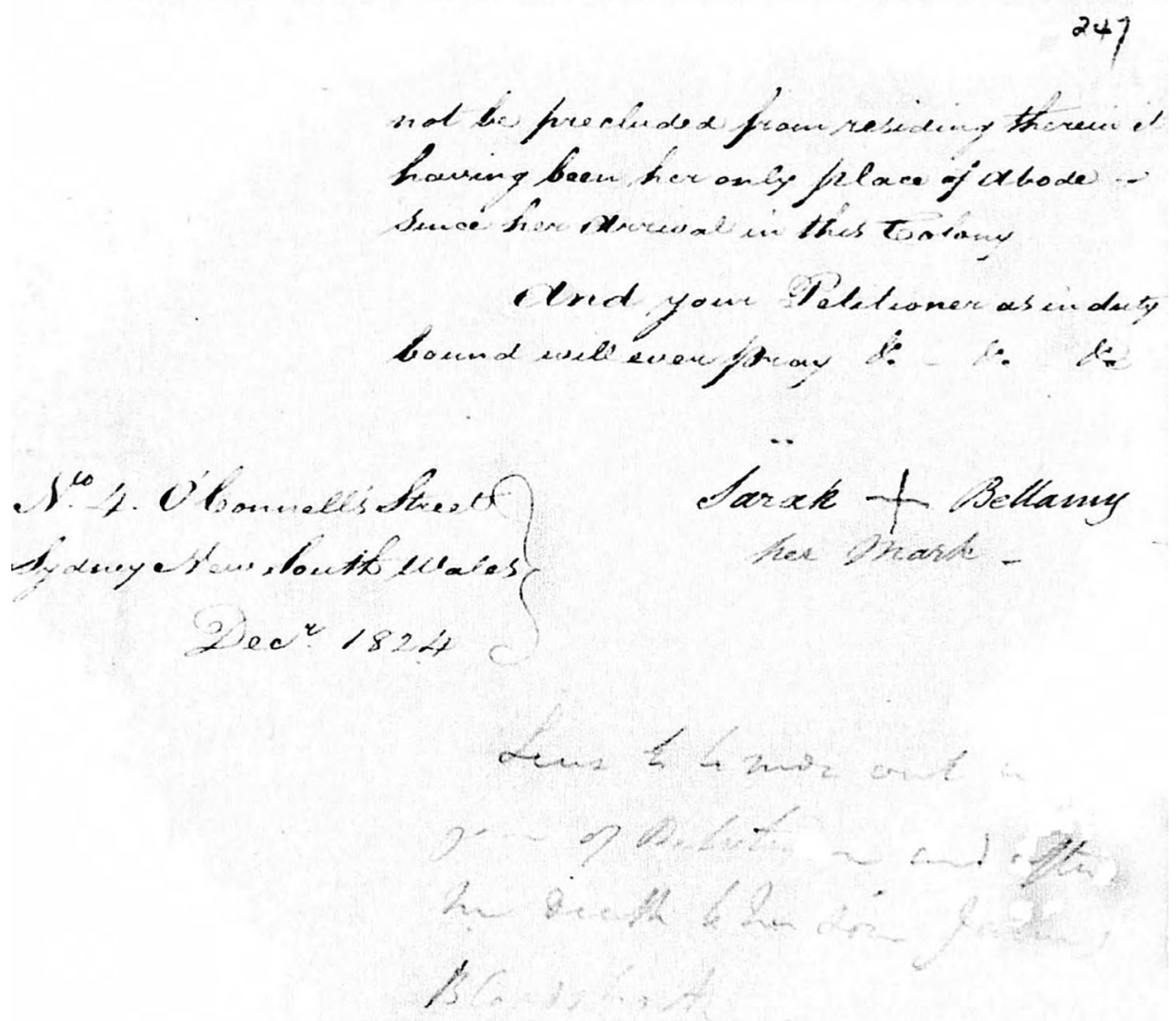

Figure 1: Sarah Bellamy's mark $X$ on a petition written on her behalf to the Governor, December 1824.

Source: NSW State Archives, NRS 899, Fiche 3077, Item 4/1836A, No. 56, pp. 245-48, NSWSA, Kingswood.

18 Data source: People Australia: First Fleet (1788) Convict Women, National Centre of Biography, The Australian National University (hereafter NCB-ANU), 2020, peopleaustralia.anu.edu.au/biographies/search/?query=eventf $\%$ $3 \mathrm{~A} \% 22$ First+Fleet+\%281788\%29\%22+occf $\% 3 \mathrm{~A} \% 22$ convict $\% 22+$ gender $\% 3 \mathrm{~A} \% 22$ Female $\% 22$. 
This view is now being contested. In 1988 Paul Carter teased out the concept of the unthinkable history of those transported:

To draw attention to the lost history of the convicts is to engage in a genuinely dialectical activity: it not only reflects critically on the dominant historical tradition, but also gives the convicts a place within it, a place from which to speak and be heard. To have let the convicts speak for themselves would have been to entertain the unthinkable: mutiny, another history. ${ }^{19}$

Given that perhaps only their social contexts might be re-created for these voiceless women, perhaps we need to move beyond the methods normally employed, as Annette Gordon-Reed has described it, creatively 'in order to piece together what they can to defeat the archives' silence'. ${ }^{20}$ We need to reimagine the depiction of the women in official records. One option is to adopt fiction writing. ${ }^{21}$ Indeed, Bellamy has been the subject of 2 fictional accounts. Mary Maclaren has written a number of accounts of the women of the First Fleet including Elizabeth's New Life (2011) in which Bellamy and others in her life (James Bloodworth and James Meredith) appear. $^{22}$ Joan Contessa Phillip has resorted to what she has described as the poetics of fiction and ficto-history-a hybrid methodology using both the archives and imagination - to write a narrative. ${ }^{23}$ She argued that this overcame the incompleteness of [the] records, their silences and partialities, the forensic reading required to contextualize them, the perspective from which the [masculinist and middle-class] narrative is told'. ${ }^{24}$ A chapter of her $2009 \mathrm{PhD}$ thesis is devoted to 'Sarah Bellamy of Belbroughton-A Poor Prisoner Speaks With Her Own Breath', most of which is made up. Writing the lives of convicts is an experiment in extending the boundaries of academic remembering. Not surprisingly, fiction or faction has been the subject of some controversy among historians. ${ }^{25}$ Could we write a great work of fiction on Bellamy? We could, but we argue here that her historical records are relatively rich. ${ }^{26}$ Indeed, when one dwells on it, the quality and quantity of records that survive for her

19 Paul Carter, The Road to Botany Bay: An Essay in Spatial History (Faber and Faber, 1988), 295.

20 Annette Gordon-Reed, review of Wayward Lives, Beautiful Experiments: Intimate Histories of Riotous Black Girls, Troublesome Women, and Queer Radicals, by Saidiya Hartman, The New York Review of Books, 22 October 2020.

21 Kate Grenville, The Secret River (Sydney: Text Publishing, 2005).

22 Mary Maclaren, The Four Elizabeths (Broadbeach Waters, Qld: Arem Storycrafters, 1993); and Mary Maclaren, Elizabeth's New Life (Bloomington, IN: Xlibris, 2011).

23 Phillip, 'Sarah Bellamy of Belbroughton Parish', v.

24 Lynette Russell, 'The Instrument Brings on Voices', Meanjin 60, no. 3 (2001): 142-51.

25 For a discussion on keeping the boundaries between history and fiction that Kate Grenville's The Secret River engendered, see Inga Glenndinen, 'The History Question. Who Owns the Past?', Quarterly Essay, no. 23 (2006): 1-72. See also 'The History Question. Response to Correspondence’, Quarterly Essay, no. 25 (2007): 73-77; Mark McKenna, 'Writing in the Past', Australian Financial Review, 16 December 2005, 16 (republished in Drusilla Modjeska, ed., Best Australian Essays 2006 [Melbourne: Black Inc., 2006]). For a wider discussion, see Sarah Pinto, 'History, Fiction and the Secret River', in Lighting Dark Places: Essays on Kate Grenville, ed. Sue Kossew (Amsterdam and New York: Rodopi, 2010), 179-98; Kate Grenville, 'The History Question. Response', Quarterly Essay, no. 25 (2007): 66-72.

26 For a discussion of constructing lives through fragments, see Annemarie McLaren, 'Reading the Entangled Life of Goggey, an Aboriginal Man on the Fringes of Early Colonial Sydney', Ethnohistory 65, no. 3 (July 2018): 489-515; Bird, 'Reconstructing a Convict Life', draft ch. 1. 
life are atypical for a First Fleet woman convict. Of course successful male convicts like Henry Kable and James Underwood have a raft of land, property and business records; she has relatively rich and revealing records of when she deals with the government, such as court cases and petitions. Her contacts - voluntary and otherwise-with the courts, government officials are considerably more informative than most. As a consequence, aspects of Bellamy's life have been used by a raft of historians to write biography, prosopography, group biography, as well as fiction.

The first biographical account was written after two of Bellamy's great-greatgreat-granddaughters, Alice and Ula Clarke, went to Belbroughton, the small Worcestershire village of their ancestor's birth. The Clarkes interested Madge Gibson, the Belbroughton History Society archivist, in Bellamy's story. They provided her with 'background information on both Sarah Bellamy and the Bloodworth family, together with transcripts of documents from Australian archives' that Gibson used with Public Record Office and Worcester Record Office material to publish a biographical account in 1987. ${ }^{27}$ The Clarkes and the Bloodworth Association, comprising family descendants, provided financial assistance. ${ }^{28}$ The 1987 biography was expanded into a more detailed account of Sarah's family and life by the Wolverhampton University reader in criminal justice history David J. Cox and Gibson (now Vaughan), in 2014. ${ }^{29}$ A United Kingdom family history website, TheGenealogist, recently featured Bellamy in an article on using Worcestershire parish records. ${ }^{30}$ Similarly, historians and historical demographers are using convict records and collective biography to write the lives of a range of female convicts like Bellamy. Biographical details of the women who were transported on the same ship as Bellamy, the Lady Penhryn, are now online on People Australia and Bellamy's life can be contextualised within her cohort by using prosopographical methods in relation to wider demographic surveys. Furthermore, a number of historians have considered her as part of collective or group biography and aspects of her life are well known. For instance, she appeared in Robert Hughes's The Fatal Shore (1988) and Thomas Keneally's The Commonwealth of Thieves (2005) and Australians (2009) as a representative First Fleet woman either in terms of being

\footnotetext{
27 Madge Gibson, Belbroughton to Botany Bay: The Story of a Worcestershire Girl's Transportation to Australia on the First Fleet and Her Life in the New Colony (Belbroughton: Belbroughton History Society, 1987).

28 Mrs Nellie Blanche Sansom OAM, nee Clarke (1913-2014), a Bloodworth descendant, formed the Bloodworth Association in the early 1980s. Nell Sansom, Bloodworth and Lee Papers, Monograph Series One (Brisbane: Social Histories Societies, 1982). See also Alice Clarke, 'James Bloodworth: First Fleeter (1759-1804)' [Speech at dedication of the plaque of James Bloodworth, 27 March 1988, Sydney Town Hall], Journal of the Fellowship of First Fleeters 19, no. 3 (May/June 1988): 4-5, accessed 5 October 2020, www.fellowshipfirstfleeters. org.au/founders/1988newsletter19i3.pdf. Research file on James Bloodworth, including copies of correspondence, research notes and photographs relating to his career as an early convict builder in Sydney, Papers of the Bloodworth family 1931-1987, MS 7975, National Library of Australia.

29 Madge Vaughan and David J. Cox, From Belbroughton to Botany Bay: The Story of a Worcestershire Girl's Transportation on the First Fleet and Her Life in the New Colony (Kingswinford: Dulston Press/Belbroughton History Society, 2014). The authors are grateful to Dave Cox for sending us a copy of this publication.

30 'Worcestershire Parish Records Trace Family Events Back through the Centuries ... Teenager Transported to Australia', The Genealogist, 3 July 2020, accessed 1 September 2020, www.thegenealogist.co.uk/featuredarticles/2020/ worcestershire-parish-records-trace-family-events-back-through-the-centuries-1272/.
} 
a poor country adolescent convict or living with a fellow convict. ${ }^{31}$ She is an example in their wider arguments. Alan Atkinson, however, puts the First Fleet women, and Bellamy in particular, at the centre of his account of the Europeans in Australia (2016), something we will return to. ${ }^{32}$

We cannot write a full 'cradle to grave' account of Bellamy's life or one that considers her inner life. Yet if we use all these biographical methods-biographical, prosopographical, demographic, collective biography-as well as a judicious and carefully considered use of fiction, her personality emerges in Australian history. Indeed, what is history if it is not drawing from the richest range of sources to write and contextualise a coherent account?

\section{Biography and the single convict case: Sarah Bellamy (1770-1843)}

Bellamy was the sixth of 8 children of Elizabeth Bellamy, née Staunton, and her husband Richard Bellamy. ${ }^{33}$ She was baptised in the local Holy Trinity Church, Belboughton, Worcestershire on 3 February $1770 .{ }^{34}$ Richard suffered ill-health and the family was poor and partly reliant upon parish charity. ${ }^{35}$ Until 1779 , the family lived in rooms in parish accommodation. ${ }^{36}$

Sarah was a child apprentice. On 7 February 1779, as a 9-year-old, she began work at the Malt House Farm, known as Bell Inn. She was contracted, probably until aged 21 or marriage, to one of the Overseers of the Poor, James Spurrier of Bell Inn, in general domestic duties, including cottage industries and farm chores and presumably dyeing and spinning. At 15 the parish arranged a place for her with a Mr and Mrs Benjamin

31 See, for example, Helen Heney, Australia's Founding Mothers (Melbourne: Thomas Nelson, 1978), 57; Don Chapman, 1788, the People of the First Fleet (North Ryde, NSW: Cassell Australia, 1981), 43; Robert Hughes, The Fatal Shore: A History of the Transportation of Convicts to Australia, 1787-1868 (London: Folio Society, 1988), 247; Thomas Keneally, The Commonwealth of Thieves (North Sydney: Penguin Random House, 2006, f.p. 2005), 29-31, 54, 68, 70, 76, 99, 123, 136, 164, 234-35; and Thomas Keneally, Australians Origins to Eureka (Crows News, NSW: Allen \& Unwin, 2009), 59, 65.

32 Alan Atkinson, The Europeans in Australia, vol. 1, The Beginning (Sydney: New South Publishing, 2016).

33 Gibson, Belbroughton to Botany Bay, 4. Elizabeth Staunton married Richard Bellamy on 16 November 1755 and their children were: Thomas (1856), Mary (1859), Elizabeth (1861), John (1766), Margaret (1767), Sarah (1770), Phebe (1775) and Richard (1776).

34 Staunton-Bellamy Marriage and Children's Baptisms: Belbroughton Parish Register (Microfilm 20/1), Worcester Library and History Centre, Trinity Street, Worcester; Belbroughton Parish Register, Baptisms, 1739-1800, Vol. 3, Worcester History Centre, Microfilm Ref: X988.52 cited by Phillip, 'Sarah Bellamy of Belbroughton Parish', 333. 35 Belbroughton Vestry Minutes records, Gibson, Belbroughton to Botany Bay.

36 Gibson (Belbroughton to Botany Bay, 4) identified the red brick dwellings, houses 4 and 8, Queens Hill, which were let 'to the overseers of the poor of Belbroughton and occupied by paupers of the said parish' and in which the Bellamys lived. In addition to housing, the family received regular payments from the parish 1774-76; and also 'linnen and necessaries during their illness of the small pox', 10 June 1769; 'necessities so that [Elizabeth] may go clean into the infirmary', 5 July 1772; as well as recording 'Richard Bellamy be relieved discretionally', 2 May 1773. Belbroughton Vestry Minutes (1769-1776), County Record Office, Worcester. 
Hadon, weavers in Dudley, a few miles distant across the Staffordshire border. Hadon had bought a fourth loom for Sarah to use but was in financial difficulties and later appeared before the Summer Assizes on a bankruptcy charge. Not long after engaging her, it seems that Hadon had overextended and had to dismiss Sarah. In response to losing her apprenticeship, on 29 May 1785, she committed grand larceny: she was charged with the theft of a small fortune, including golden guineas and promissory notes (which she could not have read), to the value of $£ 31$ 10s. 8p., from the Hadons. ${ }^{37}$ The state-appointed judge at the Summer Assizes held at Worcester, Baron Beaumont Hotham, convicted her for the theft on 9 July 1785 and sentenced her to be exiled to the colonies under the 1718 Transportation Act rather than to be hanged by the neck'. ${ }^{38}$ She pleaded to be 'publicly whipped on two successive market days' and not to be transported but her pleas were ignored.

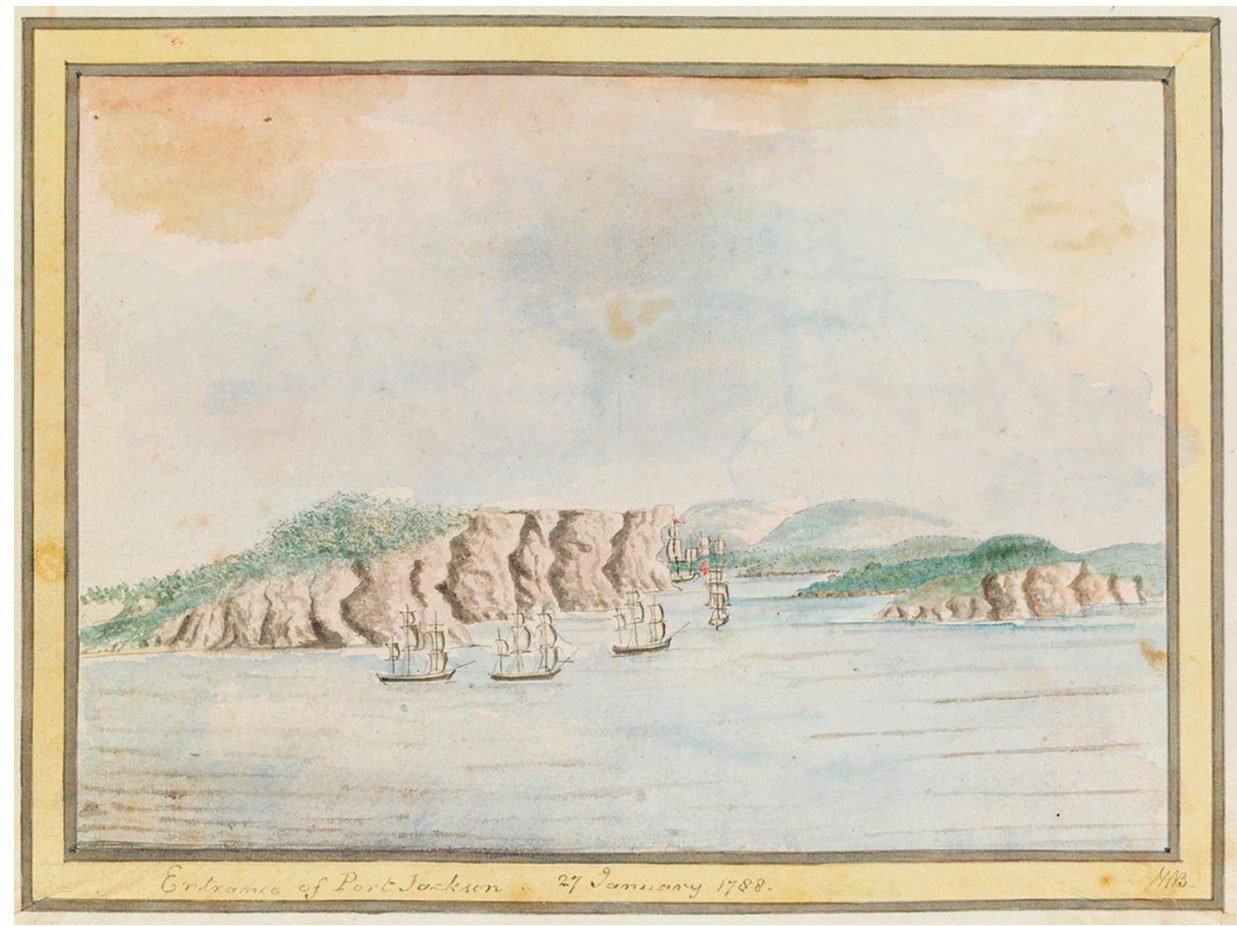

\section{Figure 2: 'Entrance of Port Jackson 27 January 1788': The arrival of the First Fleet, including the Lady Penrhyn, at Port Jackson. Watercolour by William Bradley.}

Source: State Library of NSW: William Bradley drawings from his journal 'A Voyage to New South Wales' (ca 1802).

37 Indictment of Sarah Bellamy, Worcestershire Summer Assizes, 1785, ASSI 105/36, value of theft was 630 shillings, cited by Gibson, Belbroughon go Botany Bay, 6.

38 Philip, 'Sarah Bellamy of Belbroughton Parish', 356, argued that 'If Sarah had faced an Old Bailey court she would surely have hanged'. However, Vaughan and Cox (From Belbroughton to Botany Bay, 23) point out that convicted felons who faced the death penalty were standardly given the opportunity (by means of a Royal Pardon) for their sentence to be commuted to transportation. 
Bellamy embarked on the First Fleet ship the Lady Penrhyn at Gravesend on 31 January 1787 after spending almost 2 years in gaol—this was not an unusual amount of time for first fleeters, many had spent between 3 and 5 years in gaols and hulks before being transported. The Lady Penrhyn had been built as a 2-deck slave ship on the Thames in 1786 and was designed to hold 275 slaves but it was converted to transport convicts. Bellamy found herself among the 106 female and 2 male convicts, 8 children, 37 crew and 23 marines and their families who set sail for New South Wales in May 1787..$^{9}$ Arthur Phillip, commander of the First Fleet, noted that the women boarding the Lady Penrhyn were 'almost naked and so very filthy' and diseased, and that the ship's surgeons had to first contain an outbreak of 'gaol fever' or typhus..$^{40}$ Arthur Bowes-Smyth, the ship's surgeon, recorded Bellamy's details in his inventory of convicts in his journal, noting her name, crime, trade and the term of years for which she was transported: 'Sarah Bellamy, a servant, aged 17, sentenced for seven years for privately stealing. ${ }^{41}$ Shortly before reaching Botany Bay, Sarah's son, Joseph Downey the younger, appeared on the ship's muster. ${ }^{42}$ David Cox has argued that the child's appearance in this record means it is likely that Sarah and the child's father, named as Joseph Downey, the Lady Penrhyn's quartermaster, consummated their liaison either while the ship was still at Gravesend or shortly after it had arrived at Portsmouth. ${ }^{43}$ The voyage took 252 days (36 weeks) to reach Botany Bay. The baby was baptised on 10 February 1788, died and was buried on 29 February, likely becoming the first European child interred in Australia. ${ }^{44}$ Downey senior sailed on with the Lady Penryhn on 5 May 1788, which took on a cargo of Chinese tea from Canton on the voyage back to England. ${ }^{45}$

Bellamy was assigned a 2-room hut on the east side of the Tank Stream and served as housekeeper to a naval officer, Lieutenant William Faddy, and, later, as a weaver. Her common-law husband from late 1789 was James Bloodworth, who had been sentenced on 3 October 1785 at Esher, Surrey, to 7 years transportation for the theft of a game cock and 2 hens. He arrived in New South Wales aboard the Charlotte and was the only convict listed as a bricklayer, so Governor Phillip immediately

39 Worcester Summer Assize Records, July 1785 (TNA ASSI 5/105 pts. 2 \& 3), cited by Vaughan and Cox, From Belbroughton to Botany Bay, 18.

40 Letter from Governor Phillip to Under Secretary Nepean, 18 March 1787, Historical Records of New South Wales (Sydney: Charles Potter Government Printer, 1892), 59, archive.org/stream/historicalrecord1pt2sidnuoft/ historicalrecord1pt2sidnuoft_djvu.txt, accessed 1 September 2020.

41 Paul Fidlon and R.J. Ryan, eds, The Journal of Arthur Bowes-Smyth: Surgeon, Lady Penrhyn, 1787-1789 (Sydney: Australian Documents Library, 1979), 17.

42 Mollie Gillen, The Founders of Australia: A Biographical Dictionary of the First Fleet (Sydney: Library of Australian History, 1989), 108; Vyvyen Brendon, Children at Sea: Lives Shaped by the Waves (Philadelphia: Pen and Sword, 2020), 19-20.

43 David J. Cox, Crime in England 1688-1815 (London: Routledge, 2014), 146, fn. 51. See also Vaughan and Cox, From Belbroughton to Botany Bay.

44 New South Wales Registry of Births, Deaths and Marriages, Death Certificate, Joseph Downey, 80 V4,

29 February 1788, copy issued 14 October 2020; Vaughan and Cox, From Belbroughton to Botany Bay, 33.

45 Brendon, Children at Sea, 20. 
appointed him master bricklayer. Bloodworth found a source of clay, supervised the making and burning of the first bricks, in makeshift kilns, in the wooden moulds bought out from England with the fleet, and organised the collecting of oyster shells to grind up for lime for mortar. ${ }^{46}$ The couple would likely have met when Sarah was transferred from Worcester Castle Gaol to Southwark. By 1790 Bloodworth had built Sarah a brick cottage.

Before this, however, on 1 August 1789, Bellamy was assaulted in the hut she shared with a child, by Captain James Meredith of the marines and Mr Kiltie, master of HMS Sirius. ${ }^{47}$ Meredith was in a drunken state, which apparently was not unusual for him at the time, and had, by standing on Kiltie's shoulders, tried to climb through Bellamy's window under which she was sleeping. Meredith beat the resisting Sarah about the head and face. The melee attracted the convict night watch and Meredith ordered Sarah to the guard house charged with disturbing the peace. Sarah was recorded at her trial as having:

Resolved in her own breath [that she would not] 'put up with such unmerited treatment' from Captain Meredith or anyone else. These were Sarah's words to Judge Advocate Collins: she had at last stepped from the control of that ambiguous word, poor. ${ }^{48}$

Supported by strong convict witnesses, namely Matthew Everingham, who later became a respectable settler, and the nightwatchman John Harris, the 6 men of the services headed by the Judge Advocate dismissed the charge of disturbing the peace. Sarah, perhaps wisely, did not bring charges against Meredith or Kiltie. ${ }^{49}$

Bloodworth was emancipated in 1790 for exemplary conduct, making him the second convict to be pardoned. In September 1791 he was appointed superintendent of all bricklayers. He was largely responsible for the design and erection of Australia's first buildings. 'There is not a house or building which did not owe something to him,' wrote Judge Advocate David Collins. That included the first Government House. In 1792 the governor offered him a return passage to England, but the emancipist declined. About 29 per cent of the First Fleet men left the colony after their sentence had expired (compared to only 17 per cent of First Fleet women). ${ }^{50}$ Bloodworth and Bellamy did not marry perhaps because he had left a wife, Jane Marks, whom he had married on 9 December 1782, and 4 children, in England when he was transported for stealing poultry. ${ }^{51}$ Together

\footnotetext{
46 Herman, 'Bloodsworth, James'.

47 Maclaren describes it as attempted rape, Elizabeth's New Life.

48 Gillen, Founders of Australia, 32.

49 For James Meredith's other misdemeanours in Botany Bay, the court martial which decided in his favour in 1792 and his later career in the marines, see 'James Meredith. Captain Lieutenant of Marines, 24 $4^{\text {th }}$ (Plymouth) Company', Fellowship of First Fleeters, accessed 16 September 2020, www.fellowshipfirstfleeters.org.au/jamesmeredith.htm.

50 People Australia: First Fleet (1788) Convict Women, NCB-ANU, 2020.

51 Vaughan and Cox, From Belbroughton to Botany Bay, 43.
} 
they had 8 children of whom 4 died in infancy. ${ }^{52}$ They lived comfortably, owing to James's $£ 50$ annual salary. Bloodworth started his own building business. They were granted land at Petersham, with 50 acres to James (Bloodworth Farm) and 20 to Sarah (Bellamy Farm); they increased their holding by buying a further 200 acres. Here they cleared land, sowed wheat and maize, raised hogs and kept some horses, while James continued as superintendent of bricklayers. Bellamy's family gained a respectable reputation throughout the new colony. ${ }^{53}$ In 1802 Bloodworth was made a sergeant in Sydney's Loyal Association, a mark of respect to a former convict. The association was made up of 200 volunteers recruited from citizens as a reserve or Home Guard, whose function it was to quell rebellions that may have broken out among the many convicts at liberty or as ticket of leavers, who were increasing in number.

When he died of pneumonia in 1804, Bloodworth was given a public funeral. The Sydney Loyal Association escorted the cortege with muffled drums and the body was laid in the town cemetery with military honours. ${ }^{54}$ When he died, his estate was virtually also insolvent and the next phase in Sarah's life was about to begin-as a 35-year-old single mother with 4 dependent children, ${ }^{55}$ the youngest being only 3 years old. As sole executrix, Sarah paid off debts of $£ 350$. For instance she sold 2 land grants for $£ 50 .{ }^{56}$ Governor Philip Gidley King secured her house in South Street by putting it in the name of her 14-year-old son James. Sarah lived there with her children without ever marrying or re-partnering. She rented her kitchen and an adjoining room to Jeremiah Cavanaugh, an Irish convict, in return for his teaching her youngest children, George (1796), Ann (1798) and Elizabeth (1802), to read. ${ }^{57}$ She received her certificate of emancipation on 23 February 1811. In 1823 she successfully petitioned the colonial secretary, Frederick Goulburn, for the release of her son-in-law, the ticket-of-leave holder and shoemaker Robert Carver, husband of her daughter Elizabeth, who had been, she alleged, falsely accused of 'breaking and entering, and stealing' and had been sent to Port Macquarie to continue his original life sentence. ${ }^{58}$ The family was in dire economic circumstances. He was released in 1824.59

\footnotetext{
52 James (1790-1857), John (1792-1793), Robert (1795-1795), George (1796-1840), Ann Bray (1798-1875), Elizabeth (1800-1802), Elizabeth (1802-1871), Charlotte (1804-1804), 'Bloodsworth, Sarah (1770-1843)', People Australia, accessed 1 September 2020, peopleaustralia.anu.edu.au/biography/bloodsworth-sarah-24919/text33469.

53 Quoted by Brendon, Children at Sea, 20.

54 Herman, 'Bloodsworth, James'.

55 See notices in Sydney Gazette and NSW Herald, for instance, 24 June, 28 October and 9 December 1804.

56 'Andrew Fishburn', www.fellowshipfirstfleeters.org.au/andrewfishburn.htm accessed 13 October 2020.

57 Gillen, Founders of Australia, 32.

58 Petition by Robert Carver's mother-in-law, Sarah Bellamy, for mitigation of his sentence, 4 February 1823, NRS 900, Fiche 3230, Item 4/1869, p. 21, New South Wales State Archives (NSWSA), Kingswood; Letter from Colonial Secretary Frederick Goulburn to Captain Allman, Commandant of Port Macquarie, 21 July 1823, NRS 939, Reel 6019, Item 4/3864, p. 60, NSWSA, Kingswood.

59 Petition of Elizabeth Carver for the mitigation of the sentence of her husband Robert Carver, 17 May 1824, NRS 897, Reel 6061, Item 4/1779, p. 88, NSWSA, Kingswood.
} 
Meanwhile, Sarah had faced a further downturn in her living conditions. In 1824 Sarah's oldest son, James junior, by then 34 years old and a qualified shipwright, claimed Sarah's house in O'Connell Street as his own and ordered Sarah and his sister Elizabeth to leave. Sarah petitioned the governor to intercede and provide an equal division among the 4 children, allowing her to live in the house until her death, but without success. Bellamy signed her petition to the governor, dated December 1824, with her 'X' mark. ${ }^{60}$ She was recorded as a washerwoman in the 1825 muster and living at Sarah Burgis's house in the 1828 census. She died at her daughter Elizabeth's house at Lane Cove on 24 February 1843, her cause of death unspecified but thought to be of natural causes. She was buried 2 days later at the Devonshire Street cemetery and was then later, it is believed, transferred to Botany Cemetery 6 decades later when exhumed remains were relocated to other cemeteries across Sydney to make way for the new Central Station. Sarah was survived by 3 children. ${ }^{61}$

In May 1987, the Belbroughton Historical Society unveiled a memorial plaque commemorating Bellamy's transportation on the Lady Penrhyn as part of the 200th celebration of the sailing of the First Fleet.



Figure 3: Bellamy's great-greatgreat-granddaughters, Alice and Ula Clarke, in Belbroughton to lay the commemoration plaque, 1987.

Source: Cover of Madge Gibson, Belbroughton to Botany Bay (1987).

60 Petition of Sarah Bellamy to the Governor, December 1824, NRS 899, Fiche 3077, Item 4/1836A, No. 56, pp. 245-48, NSWSA, Kingswood.

61 Gillen, Founders of Australia, 32; Rhonda Brownlow, Descendants of Bloodsworth, James and Sarah Bellamy (Kirrawee, NSW: Rhonda Brownlow, 2003). 


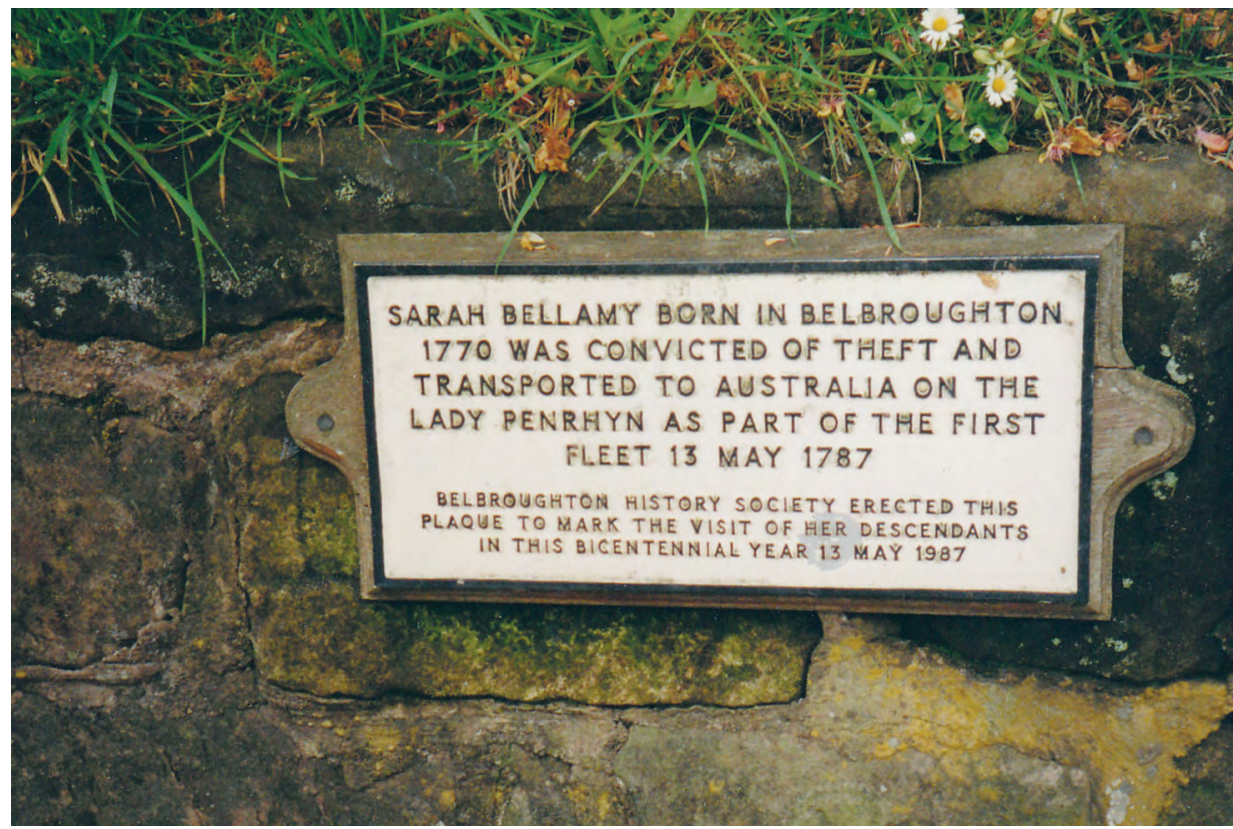

Figure 4: The plaque honouring Sarah Bellamy at Belbroughton.

Source: Vaughan and Cox, From Belbroughton to Botany Bay, 54.

\section{Prosopography: Putting Sarah into her demographical place}

Such are the biographical details of Sarah's life, sparse but considerably more informative than for most other women who were transported during the early years of the colony. Historical demography, though, can add considerable detail, particularly of context, to gain a more complete picture of Sarah's life, times and even emotional experience. Historians have been analysing statistics in regard to convicts since Leslie Lloyd Robson's The Convict Settlers of Australia (1965) set out to establish 'Who were the Convicts'. ${ }^{62}$ Mostly, convict character has been considered but increasingly there has been more general consideration of convicts' life history. ${ }^{63}$ Two major lexicons or biographical dictionaries have been published: Mollie Gillen's The Founders of Australia (1989) and Michael Flynn's The Second Fleet (1993). ${ }^{64}$ Prosopography is the investigation of the common characteristics of a historical group of people and it is often based on biographical lexicons. About 80,000 convicts were transported to New South Wales between 1788 and 1842 (85 per cent were

62 L. L. Robson, The Convict Settlers of Australia (Carlton, Vic.: Melbourne University Press, 1965).

63 S. Nicholas, ed., Convict Workers: Reinterpreting Australia's Past (Melbourne: Cambridge University Press, 1988).

64 Gillen, Founders of Australia; Michael Flynn, The Second Fleet: Britain's Grim Convict Armada of 1790 (Sydney:

Library of Australian History, 1993). 
men and 15 per cent were women). One challenge for prosopography, however, is that a range of NSW convict records were destroyed: in 1863 by fire and in 1870 by way of deliberate pulping of records. ${ }^{65}$ 'The Founders and Survivors' project, established in 2007, is tracing the lives of 73,000 convicts transported to Tasmania in the nineteenth century and following their descendants. It now has ' 1.5 million digital records of the populations who either migrated (freely or were transported) to the British colony of Van Diemen's Land (renamed Tasmania in 1856) or were born in the colony in the years $1803-1900$ '. ${ }^{66}$ It is more complete than the New South Wales archives. As mentioned, the $A D B$ is now adding biographical entries of the first 3 fleets and their families, about 110,000 lives, into its database. By navigating our way around the various lexicons and databases, we can tease out biographical aspects of Bellamy's life. Rather than considering women convicts as a whole, we can consider how typical was Sarah Bellamy in the demographic context of the late eighteenth and early nineteenth centuries and the convict system? We can follow Bellam's life course through the datasets in 4 regards: her crime, sentence and posttransportation offences; her age and voyage experience; her marriage, births and child mortality; and her mortality.

First in terms of crime, Bellamy was sentenced to 7 years' transportation for stealing a purse with money. Theft of valuables, which for women might entail clothing or cloth, was the most common crime for which convicts were transported (more than 90 per cent of women convicts) and ' 7 years' was the most common sentence. Young female convicts were more likely than the general population to be either orphans or to come from a family who could not support them. ${ }^{67}$ Most convicts (more than 80 per cent in Tasmania) had further offences recorded while under sentence, but it appears that Sarah Bellamy had none. ${ }^{68}$

Second, in terms of age while on voyage, again Bellamy is reasonably typical, although on the younger side. Bellamy was 17 years old in 1787, and while the average First Fleet woman was a decade older at 28 years, 12 per cent were aged under 20 years (Figure 5), based on an analysis of the NCB's People Australia: First Fleet (1788) Convict Women dataset.

65 Christine Shergold, 'NSW Convict Records— “Lost and Saved”', NSW State Archives \& Records, accessed 2 September 2020, www.records.nsw.gov.au/archives/collections-and-research/guides-and-indexes/stories/new-southwales-convict-records-lost.

66 'About', Founders and Survivors, accessed 1 September 2020, foundersandsurvivors.com/about/.

67 Rebecca Kippen and Janet McCalman, 'Parental Loss in Young Convicts Transported to Van Diemen's Land (Tasmania), 1841-53', History of the Family 23, no. 2 (2018): 1-23.

68 Janet McCalman and Rebecca Kippen, 'The Life-Course Demography of Convict Transportation to Van Diemen's Land', History of the Family 25, no. 3 (2020): 432-54. 


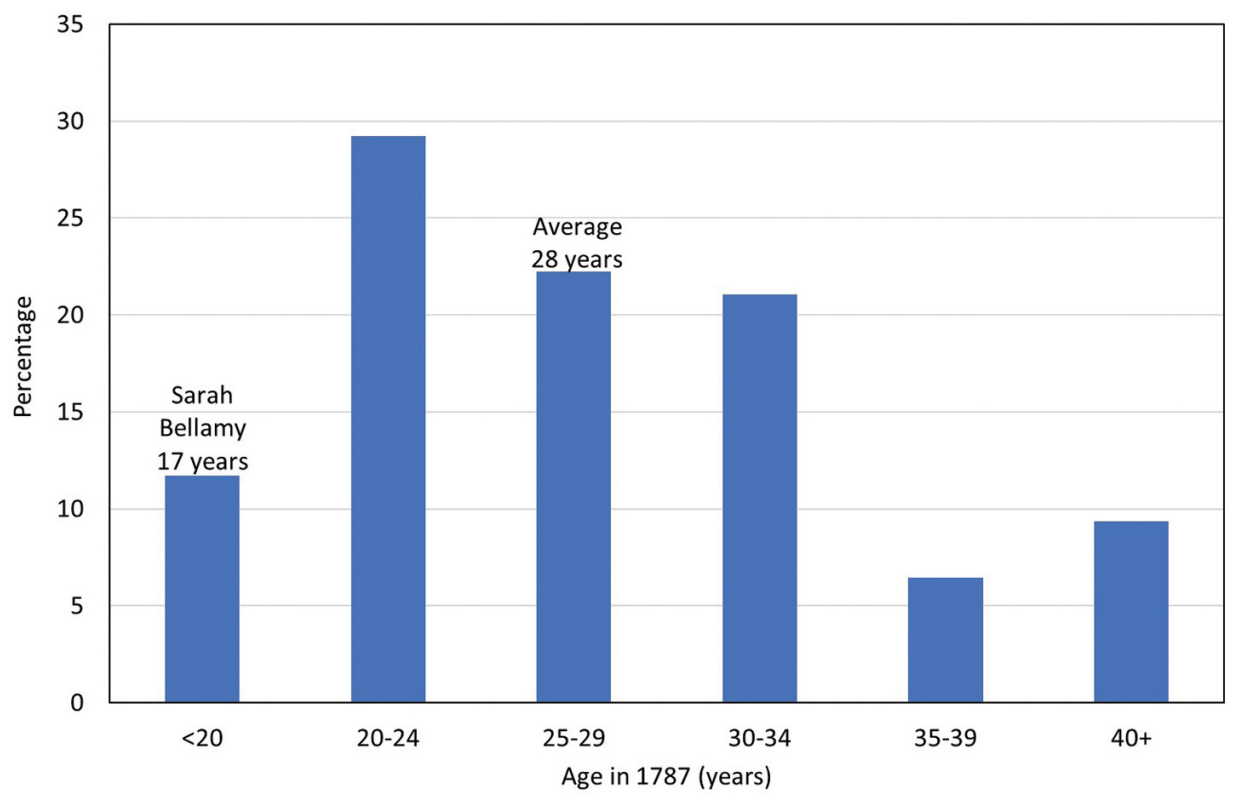

Figure 5: Percentage distribution of First Fleet convict women by age in 1787, $\mathbf{n = 1 7 1 . ~}$

Source: People Australia: First Fleet (1788) Convict Women, National Centre of Biography, The Australian National University (2020).

Third, Bellamy's experience of marriage, birth and child mortality was common. Given the huge sex imbalance (5 men for every woman), convict women tended to partner quickly. Many had births outside formal marriage. ${ }^{69}$ A large proportion of married convict women (more than 20 per cent in Tasmania) had no childrenperhaps due to sterility from sexually transmitted infections contracted in former careers as prostitutes, or working 'on the town'. Bellamy and Bloodworth had 8 children. Among Tasmanian convict women - of those who partnered and had not been 'on the town'-almost 30 per cent had 8 or more children. ${ }^{70}$ Four of Bellamy and Bloodworth's 8 children died in childhood. Sadly, infant and child mortality was high in this era. In England in the late eighteenth century, just over 50 per cent of babies survived to their 15 th birthday. ${ }^{71}$ Based on that probability, 58 per cent of families with 8 or more children lost at least 4 in childhood.

69 Peter Gunn and Rebecca Kippen, 'Convict Bastards, Common-Law Unions and Shotgun Weddings', Journal of Family History 36, no. 4 (2011): 387-403.

70 Janet McCalman and Rebecca Kippen, 'A Wise Provision of Nature for the Prevention of Too Many Children', in The Hidden Affliction: Sexually Transmitted Infections and Infertility in History, ed. Simon Szreter (Rochester, NY: University of Rochester Press, 2019), 279-302.

71 Calculated from E.A. Wrigley, R.S. Davies, R.S. Schofield and J.E. Oeppen, English Population History from Family Reconstitution, 1580-1837 (Cambridge: Cambridge University Press, 1997). 
Fourth, how typical was Bellamy in terms of her lifespan? Removing higher mortality on the voyage and the year after landing, and based on age-specific mortality rates from age 25 years, First Fleet women lived on average to 59.6 years. ${ }^{72}$ Indeed, First Fleet women were conspicuously healthy in the early years having surgeons to attend to them on the transports and government supplied food at Port Jackson (in poor supply but probably better than when convicts were in gaols and hulks before being transported). English women at this time (also based on age-specific mortality rates from age 25 years) had a very similar average life expectancy of 59.8 years. ${ }^{73}$ Thus, Sarah Bellamy, with a life span of 73 years (1770-1843), 'beat the average' by more than 13 years.

Figure 6 shows the remarkably similar survival curves for First Fleet convict women and English women. Given survival to age 25 years, 80 per cent of both populations lived to 40 years, and 56 per cent to age 60 years. One-quarter of both First Fleet convict women, and English women in general, lived to at least age 73 years (Figure 6). Bellamy, then, lived a full life in the colony but, despite suggestions, was not the oldest-lived of those transported on the First Fleet.

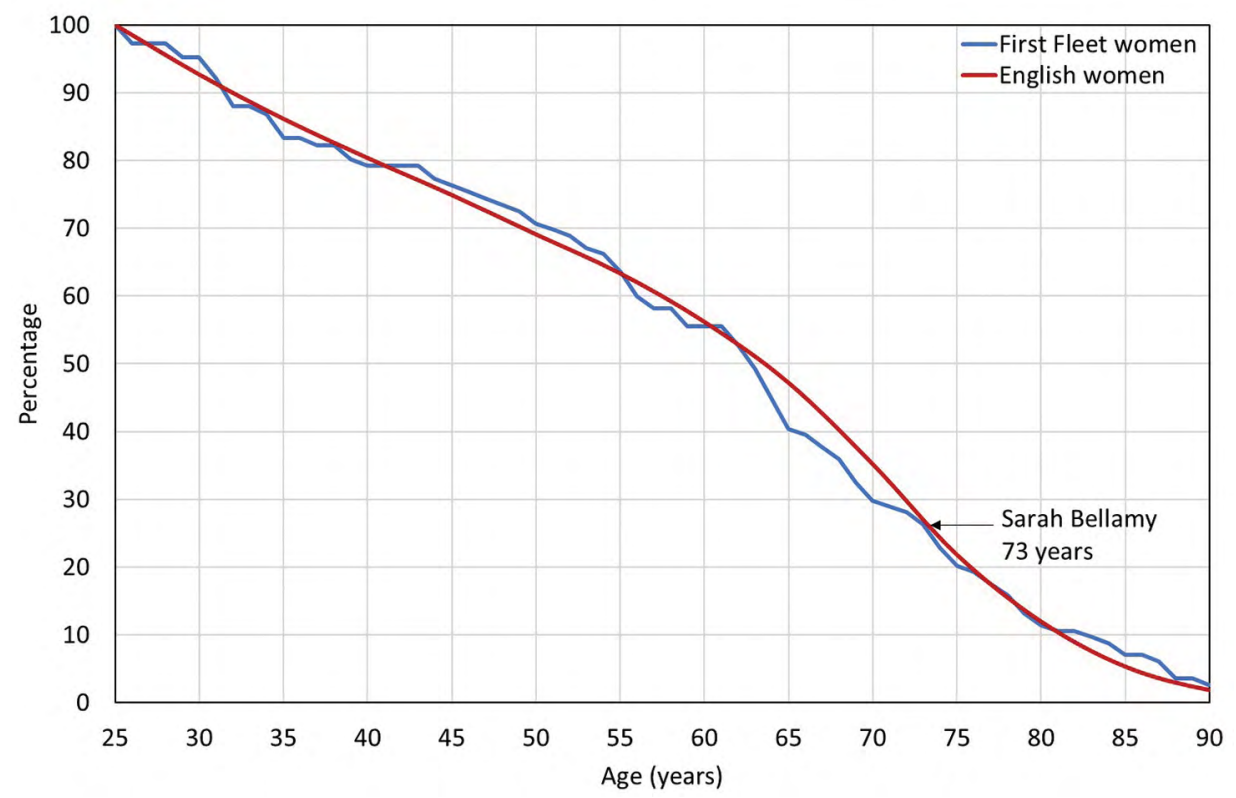

Figure 6: Percentage of survivors by age from age 25 years, First Fleet convict women $(n=104)$ and English women (1750-1809).

Source: People Australia: First Fleet (1788) Convict Women, National Centre of Biography, The Australian National University (2020); and E.A. Wrigley, R.S. Davies, R.S. Schofield and J.E. Oeppen, English Population History from Family Reconstitution, 1580-1837 (Cambridge: Cambridge University Press, 1997).

72 People Australia: First Fleet (1788) Convict Women, NCB-ANU, 2020.

73 Data source for 1750-1809 female mortality: Wrigley et al., English Population History. 
So, in conclusion, how typical was Bellamy in the demographic context of the eighteenth and nineteenth centuries and the convict system? She was average in terms of her crime and sentence. At 17 years, she was younger than most female convicts, although 12 per cent of First Fleet women were aged under 20 years. Of the 8 children she had with Bloodworth, 4 died in childhood. Just under a third of similar convict women had 8 or more children and most of these could expect to lose 4 or more in childhood. Sarah lived to 73 years, as did a quarter of First Fleet women, and English women, based on age-specific adult mortality. While Bellamy is a pretty typical female convict of her cohort, most of the historians using her life as a good example did not know the extent of her typicality.

\section{Collective biography: Bellamy and the rise of respectability, crime, sex and 'getting on'}

Sarah's life has also been used in recent collective biography. Collective biographies examine a group by considering the links and associations between its members, demonstrating how they were united in time and space. For instance, Vyvyen Brendon has considered Bellamy in terms of sexual relations between sailors and female convicts during transportation. Her life story contributes to a historiography that, rather than considering individual agency, has emphasised female convicts' uniform sexual liaisons. ${ }^{74}$ The range of convict experience in this work is often not acknowledged. Take, for instance, the number of shipboard sexual liaisons that resulted in pregnancy. As Garvey notes, the Master or (Captain) of the ship made the decision as to whether or not crew fraternised with female convicts. William Compton Severs was part owner of the Lady Penrhyn and he himself had a child with Ann Green who bore his daughter Laetitia. Bellamy, for instance, was one of at least 6 women whose relationships with the ship's crew resulted in their giving birth to children during their voyage or shortly after their arrival in Botany Bay. ${ }^{75}$ We will probably never know the reason Captain James Meredith chose Bellamy for his attempted assault on 1 August 1789 but one possible reason may have been that she had given birth to a child on board the Lady Penrhyn and so was considered a loose woman by many males in the colony. Bellamy's response shows that she did not see herself as such and was very much in control of her sexuality.

Bellamy has been the subject of 2 other collective biographies: crime sentencing in England and social relations in Australia. She became a respectable Australian. The rise in social status of convicts once in New South Wales was common as emancipists

\footnotetext{
74 Brendon, Children at Sea, 19-20.

75 Mary Mouton and Joshua Bentley, Joseph Theakson and Ann Yeats, William Curtis and Mary Branham, John Clement and Elizabeth Dalton, William Severs and Ann Green, and Joseph Downey and Sarah Bellamy. Garvey, 'Second Fleet Women, First-Rate Survivors'.
} 
were granted amounts of land that they would not likely have owned in England. As Robert Hughes and Trent Dalton suggest, Governor Phillip regarded marriage as the best path to respectability for 'felons would ... raise a native-born yeomanry'. ${ }^{76}$ In the Female Register that the Minister of St John's Paramatta Reverend Samuel Marsden compiled in 1806, women were categorised as either legally 'married' by Anglican rite or 'concubine'. Sarah was described as Bloodworth's concubine. Even Marsden admitted, however, that 'no relationship could have been more respectable, devoted or tenacious than theirs'.$^{77}$ Despite being unmarried even while Bloodworth was alive, Bellamy had a high social status and was relatively wealthy in contrast with her status as a parish child and condemned thief in England. Her biography reveals the transition from a society that put an onus on property crimes (England) to one that emphasised crimes of character (Australia). In Australia, while property was still an issue, character came to the fore. Harsh penalties were meted out to convicts who were drunk and disorderly in the street.

David J. Cox has considered Bellamy in the context of gender and prosecution in England. ${ }^{78}$ The penal code at the end of the eighteenth century concentrated on property:

There were no fewer than 250 crimes for which death was the penalty (by 1850 there were only two). Nearly all were crimes against property. That included stealing anything at all from a boat on a river (but not a canal); stealing goods worth five shillings from a shop; stealing property worth one shilling from another person; and entering with an intent to kill game or rabbits. Children as well as adults were executed. Murderous assault, however, was not a capital offense so long as the victim survived. That reflected obvious class bias: a wealthy or noble individual might commit assault, but was not likely to pick pockets. ${ }^{79}$

Bellamy illustrated what has been described as the 'subjective sentencing' associated with this 'code'. ${ }^{80}$ Crime alone was just one factor among many that judges took into account when sentencing. The sentencing standards Bellamy faced at the Assizes in July 1785 were most inconsistent. Joseph Pretty was given 6 months gaol for receiving stolen goods. Three other thieves were publicly whipped: Edward Child for breaking and entry, William Lamb for stealing shoes and John Wilmore

\footnotetext{
76 Trent Dalton, By Sea and Stars: The Story of the First Fleet (Sydney: 4th Estate, 2018), 126-30; Hughes, Fatal Shore, 245-46.

77 Hughes, Fatal Shore, 247; Portia Robinson, The Hatch and Brood of Time, A Study of the First Generation of Native-born White Australians, 1788-1828, vol. 1 (Oxford: Oxford University Press, 1985), 75-77.

78 Cox, Crime in England 1688-1815, 146, fn. 51. See also Vaughan and Cox, From Belbroughton to Botany Bay. 79 Leo Damrosch, The Club: Johnson, Boswell and the Friends Who Shaped an Age (New Haven and London: Yale University Press, 2019), 82; Jacob Viner, 'Man's Economic Status', in Man Versus Society in Eighteenth Century Britain, ed. James L. Clifford (Cambridge: Cambridge University Press, 1968), 38-39; Douglas Hay, Peter Linebaugh, John G. Rule, E. P. Thompson and Cal Winslow, Albion's Fatal Tree: Crime in Society in Eighteenth Century England (London: Verso, 2011); Cox, Crime in England 1688-1815.

80 Lucy Edwards, Convicts in the Colonies: Transportation Tales from Britain to Australia (Barnsley, South Yorkshire: Pen and Sword history, 2018), 6-7.
} 
for stealing ribbon. Richard Crump was fined 1 shilling for manslaughter. For her crime, Bellamy was transported for 7 years. It was with a sense of injustice then that Bellamy pleaded to be publicly whipped twice instead of transported. As Gibson remarked, 'it does not seem unreasonable for whipping when her crime is compared with those of her fellow defendants'. ${ }^{81}$

In many ways, Bellamy seems to have been transgressional. In 1789, she resisted a sexual assault, defiantly proclaimed her innocence and, remarkably, was believed. When she was assaulted in Australia, Sarah resolved in her own breath that she was 'not to put up with such unmerited treatment'. ${ }^{82}$ Historian Alan Atkinson uses Bellamy to make a case for a unique social order developing in Australia:

Women ... looked to the courts for a power which could override that of the men they saw about them and which could protect them in a range of matters. [More specifically, Bellamy], incidentally, helped to affirm a peculiar relationship which might exist between convict women and the law at Sydney Cove. ${ }^{83}$

While working on the First Fleeters project we have found other instances that back Atkinson's thesis, where women were appearing before courts in sexual assault cases, after having refused advances, and were believed by the courts, even though they may have been considered by some to have been 'fallen women'. Thomas Bramwell, a marine, received 100 lashes for beating Elizabeth Needham after she refused to go into the bush with him. He had had 'connections' with her on the Lady Penrhyn and thought he had a right to continue it on land. Elizabeth thought otherwise and the court agreed. ${ }^{84}$ Similarly, Mary Leary cohabited with Edward Deane, a seaman, during the voyage. He charged her with theft of clothing at Port Jackson but the charge was dismissed after it was found that he made it up because she refused to go on the ship with him. ${ }^{85}$ Similarly, a number of women successfully brought domestic violence charges against their husbands. In one remarkable case, the court ordered that the assets and children of Sophia and James Walbourne be equally split in 1800; they were given a child each.

Atkinson argued that Governor Phillip ensured that 'women's experience set the pace for the entire European project in Australia' ${ }^{86}$ English poor, like Bellamy, had experienced rights to welfare as members of parish communities. They had been 'taught to imagine that they might demand humanity from their rulers' and retained an attitude of rights. ${ }^{87}$ There was subjection and discrimination but a 3-way relationship developed between men, women and the state, which together provided

81 Gibson, Belbroughton to Botany Bay, 8.

82 Gillen, Founders of Australia, 32.

83 Atkinson, The Europeans in Australia, vol. 1: 191.

84 'Marr, Elizabeth (1762-1825)', People Australia, peopleaustralia.anu.edu.au/biography/marr-elizabeth-25391.

85 'Leary, Mary (c. 1765-?)', People Australia, peopleaustralia.anu.edu.au/biography/leary-mary-30725/text38068.

86 Atkinson, The Europeans in Australia, vol. 1: 191.

87 Atkinson, The Europeans in Australia, vol. 1: 193. 
health and education for women who did not resist. Mary MacLaren captured this attitude of rights in her fictional account of Bellamy, a brazen red-headed woman who gave others confidence to exert their agency too.

\section{Conclusion: Adding Sarah Bellamy to the ADB}

Mixed research methods allow us to tease out the singularity of Sarah Bellamy's life, compare it to other convict women's lives and consider the links and associations between her experience and others, demonstrating how they were united in time and space. This article might have been on Arthur Phillip, the first governor of New South Wales, or Governor Lachlan Macquarie, or one of the better known and significant male characters for which there has been considerable research. It might have been on Elizabeth Macquarie. It is not simply a recording of the life of an insignificant woman whose experience has been neglected for diversity's sake. It is that, but it is more than that. Choosing an 'insignificant life' does not mean that it does not reveal important aspects of the British settlement of early Australia. Sarah Bellamy's life turns out to be 'typical' in demographic terms and is a means to reflect on the early British settlement of Australia. Ironically, it is a good example to reflect upon, as Alan Atkinson, Thomas Kenneally and David J. Cox have done. Interestingly, little of this work on Sarah discusses her 'typicality'. Rather, having been 'written up' by a range of historians, a subject like Sarah becomes an example commonly referred to in the literature.

The $A D B$ is all too aware of the fraught relationship between significant and representative subjects. The journal has prided itself on its inclusion of representative subjects-more than many other national dictionary projects. Nevertheless, it is hardly representative and is engaged in several revision projects around 'decolonising' in terms of race, class and gender. The Colonial Women project, for instance, seeks to improve the gender balance of the $A D B$. Women still only account for about 12 per cent of all $A D B$ entries. For the colonial period, the situation is even more worrying, with less than 4 per cent of articles recognising women. This project will add 1,500 new entries for women who flourished during, or prior to, the colonial period. It is a large and ambitious initiative that will significantly increase the representation of women in the $A D B$. And, to finish, adding the life of Sarah Bellamy and others of her ilk, which can sustain a concise biographical essay, is a good start. 
This text is taken from Australian Journal of Biography and History: No. 4, 2020, published 2020 by ANU Press, The Australian National University, Canberra, Australia.

doi.org/10.22459/AJBH.04.2020.03 